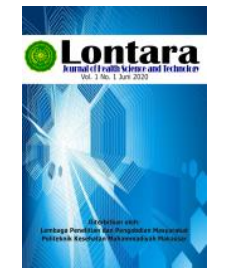

Lontara

Journal of Health Science and Technology

http://jurnal.poltekkesmu.online/lontarariset

Vol 1, No. 2, December 2020, pp 87-99

p-ISSN:0000-0000 dan e-ISSN: 2721-6179

DOI:https://doi.org/

\title{
Studi Literatur Identifikasi Jamur Pada Kuku dan Sela Kaki Penderita Diabetes Melitus
}

\author{
Anita, Nurul Ni'ma Aziz, Andi Fatmawati, Novalin Moiyo \\ Teknologi Laboratorium Medis, Politeknik Kesehatan Muhammadiyah Makassar \\ Email: anitadinar1983@gmail.com
}

\begin{tabular}{l}
\hline \multicolumn{1}{c}{ Artikel info } \\
\hline Artikel history: \\
Received;03-11-2020 \\
Revised:20-11-2020 \\
Accepted;07-12-2020
\end{tabular}

\section{Keyword:}

Literature study;

Diabetes mellitus;

Fungus; Nails; Feet.

\section{Kata Kunci:}

Studi literatur; Diabetes melitus; Jamur; Kuku; Sela kaki
Abstract. Diabetes mellitus is a disease characterized by hyperglycemia (increased blood sugar levels) that occurs due to abnormalities in insulin secretion, insulin action or both. High blood glucose levels can cause an increase in glucose levels in the skin of diabetes mellitus patients, thereby facilitating the appearance of skin manifestations in the form of dermatitis, bacterial infections, fungal infections and others. The condition of epithelial and mucosal cells of diabetes mellitus sufferers has increased adhesion to several groups of fungi on epithelial cells, namely mold and yeast. This type of research is a literature study that summarizes as many as 10 journals that are relevant to these studies. From the literature study, it turned out that 225 samples were obtained with details of 65 samples (28.9\%) tested positive for Trichophyton rubrum, Trichophyton mentagrophytes, Epidermophyton floccosum and 160 samples $(71.1 \%)$ tested negative. Based on the data from the literature study, it can be concluded that people with diabetes mellitus are at risk of being infected with the fungi that cause tinea pedis and tinea ungium, because the condition of the epithelial and mucosal cells has increased so that it makes it easier to develop fungal infections.

Abstrak. Diabetes melitus merupakan penyakit yang ditandai dengan hiperglikemia (peningkatan kadar gula darah) yang terjadi karena kelainan sekresi insulin, kerja insulin atau keduaduanya. Tingginya kadar glukosa darah dapat menyebabkan meningkatnya kadar glukosa pada kulit pasien diabetes melitus sehingga mempermudah timbulnya manifestasi kulit berupa dermatitis, infeksi bakteri, infeksi jamur dan lain-lain. Kondisi sel epitel dan mukosa penderita diabetes melitus mengalami peningkatan adesi terhadap beberapa kelompok jenis fungi pada sel epitel yaitu kapang dan khamir. Jenis penelitian ini bersifat studi literatur yang merangkum sebanyak 10 jurnal yang relevan dengan penelitian ini. Dari studi literatur diperoleh 225 sampel dengan rincian 65 sampel $(28,9 \%)$ dinyatakan positif jamur Trichophyton rubrum, Trichophyton mentagrophytes, Epidermophyton floccosum dan sebanyak 160 sampel $(71,1 \%)$ dinyatakan negatif. Berdasarkan data hasil studi literatur dapat disimpulkan bahwa penderita diabetes melitus berisiko terinfeksi jamur penyebab tinea pedis dan tinea ungium, karena 
kondisi sel epitel dan mukosa mengalami peningkatan sehingga mempermudah timbulnya infeksi jamur.

Coresponden author:

Email: anitadinar1983@gmail.com

(c) (i)

artikel dengan akses terbuka dibawah lisensi CC BY -4.0

\section{PENDAHULUAN}

Diabetes Melitus (DM) merupakan suatu kelompok penyakit metabolik dengan karakteristik hiperglikemia yang terjadi karena kelainan sekresi insulin, kerja insulin atau kedua-duanya. Diabetes melitus atau yang sering dikenal dengan kencing manis adalah penyakit yang ditandai dengan hiperglikemia (peningkatan kadar gula darah) (Stasya et al, 2018). Diabetes melitus merupakan salah satu penyakit akibat fungsi atau struktur jaringan atau organ tubuh yang menurun karena factor usia maupun gaya hidup (Phitri dan Widiyaningsih, 2013).

Hasil survei penyakit tidak menular berbasis rumah sakit di Sulawesi Selatan pada tahun 2008, penyakit diabetes melitus termasuk dalam urutan keempat penyakit tidak menular dengan prevalensi sebesar 6,65\%. Bahkan pada tahun 2010, hasil survei Dinas Kesehatan Provinsi Sulawesi Selatan menunjukkan bahwa diabetes melitus menjadi penyebab kematian tertinggi sebesar 41,56\% (Fachruddin et al, 2013).

Dinas Kesehatan Kota Makassar pada tahun 2007 menempati peringkat ke lima dari sepuluh penyebab utama kematian yaitu sebanyak 65 kasus. Pada tahun 2011 ditemukan sebanyak 5700 kasus dan melonjak pada tahun 2012 sebanyak 7000 kasus diabetes melitus dan pada tahun 2013 ditemukan kasus diabtes melitus sebanyak 1,6 juta jiwa di Sulawesi Selatan (Riskesdas, 2013).

Diabetes melitus adalah penyakit yang terjadi akibat kadar gula darah dalam tubuh manusia mengalami peningkatan dari batas normal. Akibatnya terjadi inflamasi dan penyumbatan di dalam pembuluh darah yang menimbulkan komplikasi karena darah tidak dapat mengalir dengan baik. Dampaknya adalah kerusakan organ dalam dan anggota gerak atau sering disebut kaki diabetes. Kaki diabetes adalah istilah yang terjadi adanya komplikasi pada kaki yang hanya ditemukan pada pengidap diabetes melitus. Komplikasi ini dapat berbentuk apa saja yang disebabkan kerusakan akibat tingginya kadar gula darah dan apabila terjadi luka pada kaki (Redaksi halodoc, 2017).

Tingginya kadar glukosa darah dapat menyebabkan meningkatnya kadar glukosa pada kulit pasien diabetes melitus sehingga mempermudah timbulnya manifestasi kulit berupa dermatitis, infeksi bakterial, infeksi jamur dan lain-lain. Kondisi sel epitel dan mukosa penderita. Diabetes melitus mengalami peningkatan adesi terhadap beberapa mikroorganisme patogen seperti dermatitis salah satunya Tinea pedis dan Tinea ungium (Stasya, et al, 2018).

Tinea pedis merupakan penyakit yang disebabkan oleh infeksi jamur dermatofita yang menyebabkan munculnya rasa gatal pada area kaki, jari-jari kaki serta punggung kaki. Biasanya orang 
yang terkena tinea pedis kulitnya menjadi bersisik atau melepuh serta terasa gatal pada area kaki. Penyebab dari penyakit ini adalah jamur Trichophyton rubrum, Trichophyton mentagrophytes serta Epidermophyton floccosum. Tinea pedis atau yang disebut dengan kutu air bisa menyebabkan kulit orang yang terkena menjadi bersisik atau melepuh serta rasa gatal pada area kaki (Kumar et al, 2011).

Tinea ungium merupakan infeksi jamur yang menyerang kuku jari kaki maupun jari tangan yang disebabkan oleh infeksi jamur dermatophyta dimana, kuku menjadi tebal, rapuh dan berubah warna menjadi kuning kecoklatan. Akibatnya berkurangnya sirkulasi darah masuk ke area kaki serta melemahnya sistem kekebalan tubuh dapat menjadi penyebab utama terjadinya tinea ungium. Jenis jamur yang disebabkan penyakit ini adalah Trichophyton rubrum, dan Trichophyton mentagrophytes (Brown et al, 2011).

Berdasarkan hasil penelitian di Divisi Mikologi Penyakit Kulit dan Kelamin RSUD Dr. Soetomo Surabaya tahun 2003-2005 di Indonesia, didapatkan bahwa jumlah kasus baru mikosis superfisialis menempati urutan ke-3 setelah dermatitis.Kemudian angka kejadian di Negara Indonesia berdasarkan data laporan dari seluruh Rumah Sakit pada tahun 2010 menunjukkan angka 122.076 kasus baru untuk penyakit infeksi kulit termasuk tinea pedis (Kemenkes RI, 2011).Prevalensi tinea pedis berdasarkan data statistik dari beberapa rumah sakit pendidikan di Indonesia seperti RS Dr. Soetomo pada tahun 2010 terjadi peningkatan dari tahun 2009 sebesar 7,1\% menjadi 13,2\% (Rosida dan Ervianti, 2013).

Berdasarkan hasil penelitian Amiruddin (2013), prevalensi kasus dermatofitosis yang terjadi di Makassar yaitu menempati urutan kedua setelah golongan dermatitis. Insiden ini di RS.Dr.Wahidin Sudirohusodo Makassar melaporkan terdapat 69,33\% kasus baru dermatofitosis untuk periode 20062010.

\section{METODE}

Jenis penelitian yang digunakan pada penelitian ini adalah studi literatur dengan merangkum beberapa literatur yang relevan dengan tema identifikasi jamur pada kuku dan sela kaki penderita diabetes melitus.

Penelitian ini dilaksanakan pada bulan Mei-Juli 2020. Lokasi penelitian di Politeknik Kesehatan Muhammadiyah Makassar.

Adapun yang menjadi populasi di penelitian ini adalah jurnal, Karya Tulis Ilmiah (KTI), skripsi yang berkaitan dengan jamur pada kuku dan sela jari kaki penderita diabetes mellitus. Sampel dalam penelitian ini adalah 10 jurnal yang berkaitan dengan jamur pada kuku dan sela kaki penderita diabetes mellitus. 
Teknik pengambilan sampel pada penelitian ini dilakukan dengan cara mengakses database di internet (Google, Google Scholar dengan keyword (kata kunci) sesuai dengan masalah pada penelitian sebagai berikut: Identifikasi jamur pada kuku dan sela jari kaki penderita diabetes mellitus. Adapun alur penelitian:

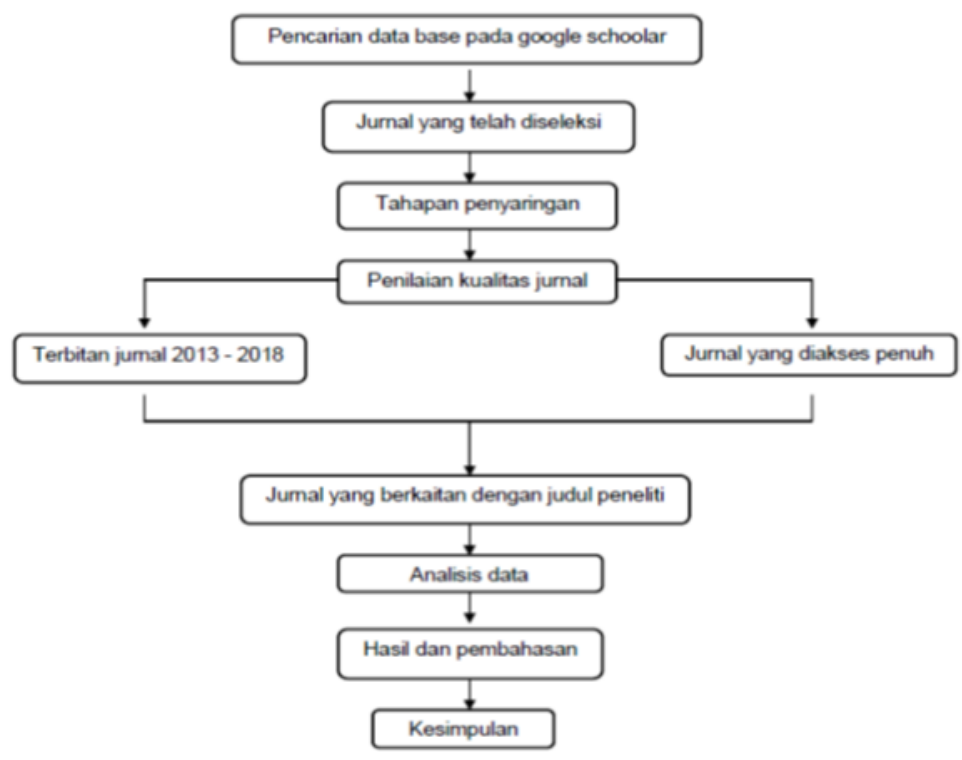

\section{HASIL DAN PEMBAHASAN}

\section{A. HASIL PENELITIAN}

Berdasarkan hasil studi literatur yang dilakukan maka diperoleh:

Tabel 1. Hasil penelitian literatur

\begin{tabular}{|c|c|c|c|c|}
\hline No & $\begin{array}{l}\text { Nama KTI, Skripsi, } \\
\text { Jurnal/ No. Volume/ } \\
\text { Tahun/ Penulis }\end{array}$ & Judul Penelitian & $\begin{array}{l}\text { Desain } \\
\text { Penelitian }\end{array}$ & Hasil Penelitian \\
\hline 1. & $\begin{array}{l}\text { Karya Tulis Ilmiah, 2018/ } \\
\text { Nila Cahyanti }\end{array}$ & $\begin{array}{l}\text { Identifikasi Jamur } \\
\text { Dermatofita Pada Kuku } \\
\text { Perajin Batu Bata Yang } \\
\text { Mengalami Kerapuhan } \\
\text { Di Dusun Karanganyar } \\
\text { Kabupaten Magetan }\end{array}$ & $\begin{array}{l}\text { Observasi } \\
\text { laboratorik }\end{array}$ & $\begin{array}{l}\text { Dari } 10 \text { sampel kuku } \\
\text { pengrajin batu bata } \\
\text { hanya } 3 \text { diantara } \\
\text { positif terdapat jamur } \\
\text { Epidermophyton } \\
\text { floccosum. } 7 \\
\text { diantaranya negatif. }\end{array}$ \\
\hline 2. & $\begin{array}{l}\text { Tesis, 2018/ Albert } \\
\text { Pandapotan }\end{array}$ & $\begin{array}{l}\text { Hubungan Antara } \\
\text { Diabetes Dengan } \\
\text { Terjadinya } \\
\text { Dermatofitosis Di } \\
\text { Puskesmas Kejuruan } \\
\text { Muda Kuala Simpang } \\
\text { Kabupaten Aceh } \\
\text { Tamiang }\end{array}$ & $\begin{array}{l}\text { Observasional } \\
\text { analitik } \\
\text { menggunakan } \\
\text { pendekatan } \\
\text { cross } \\
\text { sectional }\end{array}$ & $\begin{array}{l}\text { Dari } 80 \text { jumlah sampel } \\
\text { berdasarkan } \\
\text { pemeriksaan dengan } \\
\text { KOH didapatkan } 11 \\
\text { sampel yang (+). } \\
\text { Kemudian dilanjutkan } \\
\text { dengan penanaman } \\
\text { media di dapatkan } 6 \\
\text { sampel positif Tinea } \\
\text { corporis (T. violaceum, } \\
2 \text { T. rubrum, } T \text {. } \\
\text { mentagrophytes, } M \text {. } \\
\text { audini dan E. } \\
\text { floccosum), } 3 \text { sampel }\end{array}$ \\
\hline
\end{tabular}




\begin{tabular}{|c|c|c|c|c|}
\hline No & $\begin{array}{l}\text { Nama KTI, Skripsi, } \\
\text { Jurnal/ No. Volume/ } \\
\text { Tahun/ Penulis }\end{array}$ & Judul Penelitian & $\begin{array}{l}\text { Desain } \\
\text { Penelitian }\end{array}$ & Hasil Penelitian \\
\hline & & & & $\begin{array}{l}\text { positif Tinea cruris (2 T. } \\
\text { rubrum, } 1 T \text {. } \\
\text { mentagrophytes), } 1 \\
\text { sampel positif Tinea } \\
\text { pedis (T. } \\
\text { mentagrophytes), } 1 \\
\text { sampel positif Tinea } \\
\text { ungium (T.rubrum) }\end{array}$ \\
\hline 3. & $\begin{array}{l}\text { Karya Tulis } \\
\text { Ilmiah, 2018/ } \\
\text { Ajeng Aprilia } \\
\text { Dewanti }\end{array}$ & $\begin{array}{l}\text { Hubungan } \\
\text { Kontrol Gula Darah } \\
\text { Dengan Kejadian } \\
\text { Dermatofitosis } \\
\text { Pada Pasien Dengan } \\
\text { Riwayat Diabetes } \\
\text { Melitus Di } \\
\text { Rumah Sakit Umum } \\
\text { Daerah Dr. Moewardi } \\
\text { Surakarta }\end{array}$ & $\begin{array}{l}\text { Observasional } \\
\text { analitik }\end{array}$ & $\begin{array}{l}\text { Berdasarkan hasil } \\
\text { pemeriksaan jamur } \\
\text { dari } 64 \text { sampel } \\
\text { didapatkan } 29 \text { sampel } \\
\text { positif dermatofitosis } \\
12 \text { diantaranya adalah } \\
\text { Tinea korporis, } 7 \\
\text { Tinea kruris, dan } 4 \\
\text { sampel positif Tinea } \\
\text { pedis. } 6 \text { sampel } \\
\text { diantaranya } \\
\text { mengalami lebih dari } \\
1 \text { jenis dermatofitosis. }\end{array}$ \\
\hline 4. & $\begin{array}{l}\text { Journal.poltekkes- } \\
\text { denpasar. Vol. 6, } \\
\text { No.1, juni 2018. } \\
\text { Hlm, 56-60/ Atun } \\
\text { Farihatun, Ary } \\
\text { Nurmalasari, Ela } \\
\text { Hayati, Minceu } \\
\text { Sumirah, Doni } \\
\text { setiawan, dan } \\
\text { Panji Wahlanto. }\end{array}$ & $\begin{array}{l}\text { Identifikasi } \\
\text { Jamur Penyebab } \\
\text { Tinea Pedis Pada Kaki } \\
\text { Penyebab Karet Di } \\
\text { PTPN VIII Cikupa } \\
\text { Desa Cikupa } \\
\text { Kecamatan } \\
\text { Banjar Sari } \\
\text { Kabuapaten Ciamis } \\
\text { Tahun } 2017\end{array}$ & $\begin{array}{l}\text { Observasi } \\
\text { laboratorik }\end{array}$ & $\begin{array}{l}\text { Dari } 70 \text { sampel } \\
\text { kerokan kulit } \\
\text { didapatkan jenis jamur } \\
\text { yang positif } \\
\text { Trichophyton rubrum } \\
\text { sebanyak } 10 \text { sampel, } 2 \\
\text { sampel jenis } \\
\text { Trichophyton } \\
\text { mentagrophytes dan } \\
10 \text { sampel positif } \\
\text { jamur Aspergillus sp }\end{array}$ \\
\hline 5. & $\begin{array}{l}\text { Jurnal kesehatan bakti } \\
\text { tunas husada. Vol.18. } \\
\text { No.1 februari 2018/ } \\
\text { Khusnul, Indri, } \\
\text { Kurniawati, dan Rudy } \\
\text { Hidana. }\end{array}$ & $\begin{array}{l}\text { Isolasi Dan Identifikasi } \\
\text { Jamur Dermatophyta } \\
\text { Pada Sela-Sela Jari } \\
\text { Kaki Petugas } \\
\text { Kebersihan Di } \\
\text { Tasikmalaya }\end{array}$ & $\begin{array}{l}\text { Observasi } \\
\text { laboratorik }\end{array}$ & $\begin{array}{l}\text { Berdasarkan hasil } \\
\text { pemeriksaan jamur, dari } \\
20 \text { sampel orang petugas } \\
\text { kebersihan didapatkan } 8 \\
\text { orang terkena infeksi } \\
\text { jamur dermatopyta yaitu } \\
\text { Trichophyton rubrum } \\
\text { 15\%, Trichophyton } \\
\text { mentagrophytes 15\%, } \\
\text { Microsporum gypseum } \\
5 \% \text {, Epidermophyton } \\
\text { floccosum 5\%. Dan juga } \\
\text { ditemukan pertumbuhan } \\
\text { jamur lain didapatkan } 12 \\
\text { orang atau 60\% yaitu } \\
\text { Aspergillus sp 35\%, } \\
\text { Penicillium sp 5\%, } \\
\text { Rhizopus sp 15\% dan } \\
\text { Fusarium sp 5\%. }\end{array}$ \\
\hline 6. & $\begin{array}{l}\text { Karya Tulis Ilmiah, 2018/ } \\
\text { Izza Zuina }\end{array}$ & $\begin{array}{l}\text { Identifikasi Jamur } \\
\text { Dermatofita Pada Kuku }\end{array}$ & $\begin{array}{l}\text { Observasi } \\
\text { laboratorik }\end{array}$ & $\begin{array}{l}\text { Dari } 10 \text { sampel } \\
\text { kerokan kuku }\end{array}$ \\
\hline
\end{tabular}




\begin{tabular}{|c|c|c|c|c|}
\hline No & $\begin{array}{c}\text { Nama KTI, Skripsi, } \\
\text { Jurnal/ No. Volume/ } \\
\text { Tahun/ Penulis }\end{array}$ & Judul Penelitian & $\begin{array}{c}\text { Desain } \\
\text { Penelitian }\end{array}$ & Hasil Penelitian \\
\hline & & $\begin{array}{l}\text { Pengrajin Genteng } \\
\text { Yang Mengalami } \\
\text { Kerapuhan Di Desa } \\
\text { Pakisa Kabupaten } \\
\text { Klaten }\end{array}$ & & $\begin{array}{l}\text { pengrajin genteng } \\
\text { ditemukan } 2 \text { sampel } \\
\text { positif jenis jamur } \\
\text { dermatofita } \\
\text { Epidermophyton } \\
\text { floccosum. Dan } 7 \\
\text { diantaranya ditemukan } \\
\text { jenis jamur lain. }\end{array}$ \\
\hline 7. & $\begin{array}{l}\text { Jurnal kesehatan, } \\
\text { Pakistan. 2016. Vol. } \\
\text { 32(4): 891- 895 / Gamze } \\
\text { Akkus, Mehtap Evran, } \\
\text { Dilek Gungor, Mehmet } \\
\text { Karakas, Murat Sert dan } \\
\text { Tamer Tetiker }\end{array}$ & $\begin{array}{l}\text { Frekuensi Tinea Pedis } \\
\text { Dan Onikomikosis } \\
\text { Pada Pasien Diabetes } \\
\text { Melitus Dan Ulkus } \\
\text { Kaki Diabetes. }\end{array}$ & $\begin{array}{l}\text { Observasi } \\
\text { laboratorik }\end{array}$ & $\begin{array}{l}\text { Total pasien } 141 \\
(62,1 \%) \text { pasien } \\
\text { perempuan dan } 86 \\
(37,9 \%) \text { pasien laki- } \\
\text { laki. Yang paling } \\
\text { sering diindentifikasi } \\
\text { di Indonesia adalah } \\
\text { pasien tinea ungium } \\
(34,9 \%) \text {, dan tinea } \\
\text { pedis (26,3\%). Sekitar } \\
22,7 \% \text { dari pasien } \\
\text { wanita dan } 45,3 \% \\
\text { pasien laki-laki positif } \\
\text { terinfeksi jamur. }\end{array}$ \\
\hline 8. & $\begin{array}{l}\text { Artikel Giornale Italiano } \\
\text { di Dermatologia e } \\
\text { Venereologia, } 2013 \text { / M. } \\
\text { Papini, et al }\end{array}$ & $\begin{array}{l}\text { Mikosis kulit dan kuku } \\
\text { pada pasien dengan } \\
\text { kaki diabetes }\end{array}$ & $\begin{array}{l}\text { Observasi } \\
\text { analitik }\end{array}$ & $\begin{array}{l}\text { Penelitian ini } \\
\text { mengevaluasi infeksi } \\
\text { jamur pada kulit kaki } \\
\text { dan kuku pada } 75 \\
\text { sampel dengan } \\
\text { penyakit diabetes yang } \\
\text { memilki komplikasi } \\
\text { pada kaki, } \\
\text { menunjukan } \\
\text { prevalensi yang sangat } \\
\text { tinggi dari kedua jenis } \\
\text { infeksi ini, tinea pedis } \\
\text { diamati pada } 46,7 \% \\
\text { dan onimikosis pada } \\
53,3 \% \text { dari pasien ini } \\
\text { versus pervelensi } \\
14,7 \% \text { dan } 22,7 \% \\
\text { masing-masing dalam } \\
\text { kontrol yang cocok. }\end{array}$ \\
\hline 9 & $\begin{array}{l}\text { International Journal } \\
\text { dermatology, Turkey. } \\
\text { 2016. Vol. 56(1) / } \\
\text { Yasemin Oz, iman } \\
\text { qoraan, Ali oz dan Ilknur } \\
\text { balta }\end{array}$ & $\begin{array}{l}\text { Pravalensi dan } \\
\text { epidemologi tinea pedis } \\
\text { dan kuku kaki } \\
\text { onikomikosis dan } \\
\text { kerentanan antijamur } \\
\text { penyebab agen pada } \\
\text { pasien diabetes tipe } 2 \text { di } \\
\text { turki }\end{array}$ & $\begin{array}{l}\text { Observasi } \\
\text { analitik }\end{array}$ & $\begin{array}{l}\text { Sebanyak } 600 \text { pasien } \\
\text { diabetes melitus ( } 185 \\
\text { laki-laki dan } 415 \\
\text { perempuan).Ada } 152 \\
\text { pasien control tanpa } \\
\text { diabetes (40 laki-laki } \\
\text { dan } 112 \text { perempuan) di } \\
\text { masukkan dalam } \\
\text { penelitian ini. Usia rata- } \\
\text { rata } 58 \text { tahun. Sebanyak } \\
459 \text { sampel kulit atau } \\
\text { kuku di peroleh dari } 328\end{array}$ \\
\hline
\end{tabular}




\begin{tabular}{|c|c|c|c|c|}
\hline No & $\begin{array}{c}\text { Nama KTI, Skripsi, } \\
\text { Jurnal/ No. Volume/ } \\
\text { Tahun/ Penulis }\end{array}$ & Judul Penelitian & $\begin{array}{c}\text { Desain } \\
\text { Penelitian }\end{array}$ & Hasil Penelitian \\
\hline & & & & $\begin{array}{l}\text { pasien diabetes dan } 43 \\
\text { pasien kontrol yang } \\
\text { setidaknya memiliki satu } \\
\text { lesi yang mencurigakan } \\
\text { untuk mikosis } \\
\text { superficial diamati pada } \\
\text { kaki. Pada kelompok } \\
\text { diabetes lesi diamati di } \\
\text { daerah interdigital, pada } \\
\text { kuku ada } 127 \text {, pada kuku } \\
\text { ada } 123 \text { pasien dan di } \\
\text { kedua wilayah intergital } \\
\text { dan kuku di } 78 \text { pasien. } \\
\text { Pada kelompok kontrol, } \\
\text { lesi diamati pada daerah } \\
\text { interdigital pada } 13 \\
\text { pasien, pada kuku ada } 20 \\
\text { pasien, dan pada kedua } \\
\text { wilayah interdigital dan } \\
\text { kuku pada } 10 \text { pasien. } \\
\text { Frekuensi onimikosis } \\
\text { dan tinea pedis keduanya } \\
\text { signifikan pada pasien } \\
\text { diabetes dari pada pasien } \\
\text { kontrol. }\end{array}$ \\
\hline 10. & $\begin{array}{l}\text { Artikel penelitian dan } \\
\text { peraktek keperawatan, } \\
\text { 2015 / Kimie Takehara, et } \\
\text { al. }\end{array}$ & $\begin{array}{l}\text { Hubungan antara residu } \\
\text { cuci pada kaki dan tinea } \\
\text { pedis pada pasien } \\
\text { diabetes }\end{array}$ & $\begin{array}{l}\text { Observasi } \\
\text { analitik }\end{array}$ & $\begin{array}{l}\text { Dari } 145 \text { kandidat } \\
\text { yang menderita } \\
\text { diabetes, } 33 \text { pasien } \\
\text { yang di libatkan dalam } \\
\text { penelitian ini,27 } \\
\text { peserta menderita } \\
\text { diabetes tipe } 2 \text {, durasi } \\
\text { diabetes } 8,6 \text { tahun, } 6 \\
\text { pasien memiliki kaki } \\
\text { kelainan bentuk, } 17 \\
\text { pasien memiliki } \\
\text { riwayat tinea pedis. }\end{array}$ \\
\hline
\end{tabular}

Sumber: Data Sekunder, 2013-2018

\section{B. PEMBAHASAN}

Berdasarkan penelitian Nila (2018) menggunakan metode secara langsung dan secara tidak langsung dengan jumlah sampel 10, dinyatakn positif 3 (30\%) terdapat jamur Trichophyton rubrum, Trichophyton mentagrophytes, Epidermophyton floccosum dan dinyatakan negatif 7 sampel (70\%). Metode secara langsung menggunakan larutan $\mathrm{KOH} \mathrm{40 \% .} \mathrm{Metode} \mathrm{secara} \mathrm{tidak} \mathrm{langsung} \mathrm{dilakukan}$ dengan cara pembiakan pada medium Sabouraud Dextrose Agar. Pada semua sampel dilakukan pemeriksaan secara langsung dengan menggunakan $\mathrm{KOH} 40 \%$ dilihat secara mikroskopis tidak menunjukkan adanya elemen jamur karena mempunyai nilai yang bervariasi dan tidak konsisten, hal ini kemungkinan dipengaruhi oleh keterampilan dalam menginterpretasi keberadaan elemen jamur. 
Selanjutnya pemeriksaan secara tidak langsung sampel kuku yang sudah dikerok dan dipotong, dimasukkan ke dalam cawan petri steril menggunakan kapas lidi steril yang dibasahi aquadest steril. Kemudian dilakukan inokulasi perataan pada medium Sabouraud Dextrose. Kerokan dan potongan kuku yang sudah dilakukan perataan diinkubasi selama 7 hari dan diidentifikasi untuk mengetahui jenis jamur yang terdapat pada kuku perajin batu bata, koloni diambil yang berwarna putih karena ciriciri dari jamur dermatofita. Hasil penelitian menunjukkan bahwa tiga cawan petri ditumbuhi koloni jamur dermatofita dengan spesies Epidermophyton floccosum. Morfologi pertumbuhan koloni berwarna putih, meninggi, dan melipat di bagian tengah. Gambaran dari mikroskopis memiliki makrokonidia berdinding halus, tipis, berbentuk tongkat, terdiri dari 2-4 sel, dan tidak memiliki mikrokonidia.

Berdasarkan hasil pemeriksaan oleh Albert (2018) menggunakan metode secara langsung dan secara tidak langsung dengan jumlah sampel 80 kerokan skuama yang dilakukan pemeriksaan $\mathrm{KOH}$ 40\% didapatkan $11(13,75 \%)$ sampel positif dermatofitosis dan dinyatakn negatif ada $69(86,25 \%)$ sampel. Kemudian dilanjutkan dengan penanaman pada media Saboroud Dextrose Agar didapatkan tinea corporis dengan tipe jamur yang bervariasi, berjumlah 6 masing-masing penyebabnya 1 Tricophyton violaceum, 2 Tricophyton rubrum, 1 Mycosporum audini, 1 Tricophyton mentagrophytes, 1 Epidermophton floccosum. Tinea cruris berjumlah 3 penyebabnya 2 Trichophyton rubrum, 1 Trichophyton mentagrophytes, dan 1 sampel positif Tinea pedis penyebab Trichophyton mentagrophytes, 1 sampel positif Tinea ungium penyebab Trichophyton rubrum. Penderita Diabetes melitus di Puskesmas Kejuruan Muda Kuala Simpang Kab. Aceh Tamiang dengan lama menderita kurang lebih $\geq 5$ tahun 44 orang (55\%) lebih banyak dari pada pasien lama menderita $\mathrm{DM}<5$ tahun sebanyak 36 orang (45\%). Dimana semakin lama menderita diabetes melitus maka, semakin tinggi pula komplikasi yang dialami oleh pasien.

Penelitian yang dilakukan oleh Ajeng (2018) menggunakan metode secara langsung dan secara tidak langsung dengan jumlah sampel 64, sampel dinyatakan positif sebanyak 29 (45\%) terdapat jamur Trichophyton rubrum, Trichophyton mentagrophytes, Epidermophyton floccosum dan sampel dinyatakn negatif sebanyak 35 (54\%).Metode secara langsung menggunakan larutan $\mathrm{KOH}$ 40\%. Metode secara tidak langsung dilakukan dengan cara pembiakan pada medium Sabouraud Dextrose Agar.Penelitian ini dilakukan di bagian Rekam Medik RSUD Dr. Moewardi Surakarta.Populasi dalam penelitian ini adalah seluruh pasien yang berobat ke Poli Klinik Kulit dan Kelamin yang memiliki riwayat diabetes melitus.Dalam penelitian yang dilakukan terdapat hubungan antara kontrol gula darah dengan kejadian dermatofitosis pada pasien dengan riwayat diabetes melitus di RSUD Dr. Moewardi Surakarta.

Berdasarkan penelitian Atun et al (2017) menggunakan metode secara langsung dan secara tidak langsung dengan jumlah sampel 60, sampel dinyatakan positif sebanyak 12 (20\%) terdapat jamur Trichophyton rubrum, Trichophyton mentagrophytes, Epidermophyton floccosum dan sampel dinyatakn negatif sebanyak 48 (80\%). Metode secara langsung menggunakan larutan $\mathrm{KOH} 40 \%$. 
Metode secara tidak langsung dilakukan dengan cara pembiakan pada medium Sabouraud Dextrose Agar.Tenik sampling dilakukan secara incidental sampling dengan kreteria inklusi dan eksklusi.Pengumpulan data dilakukan dengan wawancara dan pemeriksaan laboratorium, dengan prosedur kerja meliputi tahapan persiapan alat dan pembuatan media, penanaman sampel pada media serta pemeriksaan sampel.

Berdasarkan penelitian yang dilakukan Khusnul et al (2018) menggunakan metode secara langsung dan secara tidak langsung dengan jumlah sampel, sampel dinyatakan positif sebanyak 8 (40\%) dan sampel dinyatakn positif jamur lain sebanyak 12 (60\%).Metode secara langsung menggunakan larutan $\mathrm{KOH}$ 40\%.Metode secara tidak langsung dilakukan dengan cara pembiakan pada medium Sabouraud Dextrose Agar. Dari hasil pemeriksaan jamur Dermatophyta pada sela-sela jari kaki didapatkan jamur Dermatophyta yaitu Trichophyton rubrum sebanyak 15\%, Trichophyton mentagrophytes sebanyak 15\%, Microsporum gypseum sebanyak 5\%, Epidermophyton floccosum sebanyak 5\%, juga ditemukan pertumbuhan jamur lain didapatkan 12 orang atau $60 \%$ yaitu Aspergillus sp sebanyak 35\%, Penicillium sp sebanyak 5\%, Rhizopus sp sebanyak 15\%, dan Fusarium sp sebanyak 5\%.Adapun metode yang digunakan yaitu deskriptif dengan teknik pengambilan sampel purposive sampling dengan jumlah sampel 20.Pengumpulan data primer dilakukan dengan pemeriksaan langsung jamur secara makroskopis dan mikroskopis, serta data sekunder diperoleh dengan kuesioner.

Berdasarkan penelitian Izzah ( 2018) menggunakan metode secara langsung dan secara tidak langsung dengan jumlah sampel 10, sampel dinyatakan positif sebanyak 2 (20\%) terdapat jamur Epidermophyton floccosum, sampel dinyatakan positif jamur lain sebanyak 7 (70\%) dan 1 (10\%) dinyatakan negatif.

Metode secara langsung menggunakan larutan $\mathrm{KOH}$ 40\%.Metode secara tidak langsung dilakukan dengan cara pembiakan pada medium Sabouraud Dextrose Agar.Dari hasil penelitian ditemukan adanya jamur dermatofita dimana jenis jamur dermatofita yang terdapat pada kuku perajin genteng yang mengalami kerapuhan yaitu Epidermophyton floccosum.

Berdasarkan penelitian yang dilakukan Gamze (2016) tentang "Frekuensi tinea pedis dan onikomikosis pada pasien diabetes mellitus dan ulkus kaki diabetes" dimana didapatkan tidak dilakukan pemeriksaan laboratorium. Hanya melakukan riset dengan memberikan formulir kuesioner serta wawancara tatap muka dengan persetujuan pasien.

Berdasarkan penelitian M. Papini et al (2013) dengan judul "Mikosis kulit dan kuku pada pasien dengan kaki diabetes" sama halnya dengan penelitian diatas, tidak dilakukan pemeriksaan laboratorium tetapi hanya memberikan pertanyaan secara tatap muka serta melakukan riset pendataan dengan cara meminta data rekam medis pasien, berdasarkan hasil riset yang dilakukan, bahwa pasien diabetes melitus terinfeksi tinea pedis dan onimikosis. 
Berdasarkan penelitian Yasemin et al (2016) tentang "Pravalensi dan epidemologi tinea pedis dan kuku kaki onikomikosis dan kerentanan anti jamur penyebab agen pada pasien diabetes tipe 2 di Turki“ yaitu hanya melihat perkembangan onimikosis atau tinea pedis yang berhubungan signifikan untuk diabetes melitus tipe 2 dengan bertambahnya usia, tetapi tidak melakukan pemeriksaan laboratorium secara spesifik. Jamur yang paling umum ditemukan adalah Trichophyton rubrum, sebanyak 600 sampel diabetes dan 152 sampel kontrol dievaluasi. Tingkat onimikosis dan tinea pedis pada pasien diabetes,usia, jenis kelami, kadar glukosa darah, durasi diabetes dan profil serum lipid diselidiki.

Berdasarkan penelitian Takehara et al (2015) tentang "Hubungan antara residu cuci pada kaki dan tinea pedis pada pasien diabetes" didapatkan bahwa pasien diabetes yang terkena tinea pedis tidak memperhatikan kebersihan pada area kaki. Sama halnya pada penelitian diatas, tidak melakukan pemeriksaan laboratorium tetapi hanya melakukan pendataan serta melihat kaki seseorang yang telah terinfeksi tinea pedis dan dilakukan pengambilan foto pada kaki, kemudian specimen kulit dan kuku dikumpulkan jika ada lesi seperti sisik, vesikel, kuku berwarna, penebalan kuku untuk mengetahui ada tidaknya tinea pedis, dan foto kaki yang tidak di cuci diambil di bawah sinar UV.

Berdasarkan studi literature dari 10 jurnal dapat disimpulkan bahwa pada penelitian Nila (2018) dari 10 jumlah sampel di dapatkan hanya 3 positif terdapat jamur Epidermophyton floccosum, dan 7 diantaranya negatif. Dari hasil jurnal Albert Pandapotan (2018) dari 80 jumlah sampel berdasarkan pemeriksaan dengan $\mathrm{KOH}$ didapatkan 11 sampel yang (+). Kemudian dilanjutkan dengan penanaman media didapatkan 6 sampel positif Tinea corporis (T. violaceum, 2 T. rubrum, T.mentagrophytes, $M$. audini dan E. floccosum), 3 sampel positif Tinea cruris (2 T. rubrum, $1 \mathrm{~T}$. mentagrophytes), 1 sampel positif Tinea pedis (T.mentagrophytes), 1 sampel positif Tinea ungium ( $T$. rubrum).

Penelitian Ajeng (2018) didapatkan hasil pemeriksaan dari 64 sampel didapatkan 29 sampel positif dermatofitosis 12 diantaranya adalah Tinea korporis, 7 Tinea kruris, dan 4 sampel positif Tinea pedis. 6 sampel diantaranya mengalami lebih dari 1 jenis dermatofitosis. Pada Penelitian Atun (2018) dari 70 jumlah sampel didapatkan positif Trichophyton rubrum sebanyak 10 sampel, 2 sampel jenis Trichophyton mentagrophytes dan 10 sampel positif jamur Aspergillus sp.

Berdasarkan hasil penelitian Khusnul, et.al (2018) dari 20 sampel, didapatkan 8 positif jamur (Trichophyton rubrum 15\%, Trichophyton mentagrophytes 15\%, Microsporum gypseum 5\%, Epidermophyton floccosum 5\%). Selain itu ditemukan juga pertumbuhan jamur lain sebanyak 12 sampel yaitu Aspergillus sp. 35\%, Penicillium sp. 5\%, Rhizopus sp. 15\% dan Fusarium sp. 5\%. Berdasarkan penelitian Izza (2018) dari 10 jumlah sampel ditemukan 2 sampel positif Epidermophyton floccosum dan 7 diantaranya ditemukan Aspergillus sp. dan Microsporum gypseum.

Pada penelitian Gamze (2016) yang dilakukan dengan observasi analitik pada $141(62,1 \%)$ pasien perempuan dan 86 (37,9\%) pasien laki-laki. Kejadian yang paling sering diindentifikasi di Indonesia adalah pasien tinea ungium (34,9\%), dan tinea pedis (26,3\%). Sekitar 22,7\% dari pasien 
wanita, dan 45, 3\% pasien laki-laki positif terinfeksi jamur. Pada penelitian M. Papini (2013) yang dilakukan dengan observasi analitik untuk mengevaluasi infeksi jamur pada kulit kaki dan kuku pada 75 sampel dengan penyakit diabetes yang memiliki komplikasi pada kaki, menunjukkan prevalensi yang sangat tinggi dari kedua jenis infeksi ini, tinea pedis diamati pada $46,7 \%$ dan onimikosis pada $53,3 \%$ dari pasien. versus pervelensi $14,7 \%$ dan $22,7 \%$ masing-masing dalam kontrol yang cocok.

Berdasarkan penelitian Yasemin (2016) yang dilakukan dengan observasi analitik didapatkan frekuensi onimikosis dan tinea pedis yang signifikan pada pasien diabetes. Dalam kelompok diabetes, onimikosis dan tinea pedis terdeteksi $85(14,2 \%)$ pasien diantaranya 39 memiliki onimikosis, 28 menderita tinea pedis, dan 18 menderita onimikosis dan tinea pedis. Penelitian Kimie (2015) yang dilakukan dengan observasi analitik didapatkan 27 peserta menderita diabetes tipe 2, durasi diabetes 8,6 tahun, 6 pasien memiliki kaki kelainan bentuk, 17 pasien memiliki riwayat tinea pedis.

Penderita Diabetes Melitus sangat rentan mengalami infeksi pada kaki karena terjadinya kematian atau kerusakan pada jaringan kaki. Selain itu, peningkatan kadar gula darah yang tinggi dapat menyebabkan timbulnya luka-luka kecil pada kaki sehingga terjadinya infeksi. Faktor yang dapat memicu terjadinya infeksi pada kaki terjadi karena kebiasaan makan makanan yang mengandung banyak gula, kebiasaan merokok dan mengkonsumsi minuman beralkohol. Terjadinya kematian jaringan pada kaki dapat memicu terjadinya infeksi tinea pedis (Redaksi halodoc, 2018).

Tingginya gula darah dapat mengubah cara kerja sistem saraf dan merangsang produksi zat sitokin dalam tubuh. Sitokin adalah hormon yang jika diproduksi berlebihan menyebabkan peradangan. Reaksi ini membuat kulit pengidap diabetes melitus menjadi gatal, kering, dan pecahpecah. Kadar gula darah yang lebih tinggi dari batas normal juga meningkatkan risiko infeksi di kulit tangan, kaki, hingga area organ intim. Penyebabnya bisa karena infeksi jamur, salah satunya Tinea pedis (Redaksi Halodoc, 2018).

Jamur penyebab tinea pedis umumnya menyerang bagian kulit yang lembab, kurangnya sirkulasi udara, dan tidak terkena sinar matahari. Jenis jamur yang menyebabkan tinea pedis antara lain jamur Trichophyton dan Epidermophyton. Jamur yang menyebabkan tinea pedis biasanya kecil, hanya terlihat di bawah mikroskop, dan memiliki kemampuan untuk berkembang di lingkungan yang hangat dan lembab. Selain itu, orang dengan perubahan hormon dalam tubuh membuat sistem kekebalan tubuh lemah dan rentan terhadap jamur pada kulit dibandingkan dengan kondisi normalnya (Redaksi Halodoc, 2017).

\section{KESIMPULAN}

Berdasarkan hasil review yang berkaitan dengan "studi literatur identifikasi jamur pada kuku dan sela kaki penderita diabetes melitus" yang merangkum sebanyak 10 jurnal yang relevan dengan penelitian ini. Dari 10 jurnal ternyata diperoleh 225 sampel dengan rincian 65 (28,9\%) dinyatakan positif jamur Trichophyton rubrum, Trichophyton mentagrophytes, Epidermophyton floccosum dan 
dengan rincian $160(71,1 \%)$ dinyatakan negatif. Berdasarkan data hasil studi literatur dapat disimpulkan bahwa penderita diabetes melitus berisiko terinfeksi jamur penyebab tinea pedis dan tinea ungium.

\section{SARAN}

Sebaiknya peneliti selanjutnya melakukan uji sensitivitas antijamur pada jamur penyebab tinea pedis dan tinea unguim.

\section{UCAPAN TERIMA KASIH}

Terima kasih diucapkan kepada Direktur, Kaprodi D3 TLM yang telah memberikan izin penelitian, dan seluruh civitas akademika prodi TLM Politeknik Kesehatan Muhammadiyah Makassar serta pihak Laboratorium Bakteriologi TLM Politeknik Kesehatan Muhammadiyah Makassar yang telah membantu terlaksananya seluruh rangkaian penelitian ini.

\section{DAFTAR PUSTAKA}

Amiruddin, M. D. 2013. Penyakit Kulit Di Daerah Tropis Dan Penyakit Kusta Da;Am Bidang Kedokteran. LKKP Universitas Hasanuddin.Makassar.

Arisman 2011. Buku Ajar Ilmu Gizi Obesitas, Diabetes Melitus, Dan Dislipidemia, Konsep Teori Dan Penanganan Aplikasi, EGC, Jakarta

Badan Penelitian dan Pengembangan Kesehatan Kementerian Kesehatan RI (Balitbang Depkes RI). 2013. Riset Kesehatan Dasar (Riskesdas): Laporan Nasional. Jakarta: Depkes RI.

Brown, Robin Graham, Johnny Bourke, Tim Cunliffe. 2011. Dermatology Dasar untuk Praktik Klinik. Jakarta: Penerbit Buku Kedokteran EGC

Djuanda, A. 2013. Ilmu Penyakit Kulit dan Kelamin. Jakarta: Fakultas kedokteran Universitas Indonesia. Edisike-6

Fachruddin, Ismi, Irfiyanti, Citrakesumasari \& Sri'ah, A. 2013. Effort of caring and behavior of patiens of diabetes melitus type 2 at bara-baraya Health Center Makassar in 2013. Jurnal MKMI [Online journal] 2013; 1-2.

Fajri, Muhammad. 2016. Karakteristik Pasien Dermatofitosis Superfisial di Poliklinik Kulit dan Kelamin RSUP DR. Wahidin Sudirohusodo pada Periode Januari-Desember 2016. Skripsi tidak diterbitkan. Makassar: Fakultas kedokteran Universitas Hasanuddin

Irianto, K. 2014. Bakteriologi, Mikrobiologi dan Virologi. Bandung : Penerbit Alfabeta

Kemenkes Republik Indonesia 2011.Profil Kesehatan Indonesia Tahun 2010.Kementrian Kesehatan Republic Indonesia, (http://www.kemenkes.go.id), diakses 26 januari 2020.

Kidd, S.,Halliday, C.,Alexiou, H.,Ellis, D. 2016. National Micology Reference Centre Sa Pathology, Adelaide, South Australia. Descriptions Of Medical Fungi.

Kumar, V., Tilak, R., Prakas, P., Nigam, C., 2011. Tinea pedis- an Update. Asian journal of medical sciences. Vol 2: 134-8 
Phitri, S.H dan Widianingsih. 2013. Hubungan antara pengetahuan dan sikap penderita diabetes mellitus dengan kepatuhan diet diabetes mellitus di RSUD AM. Parikesit Kalimantan timur. Jurnal keperawatan medical bedah. Hal. 54-74.

Redaksi Halodoc. 14 Desember 2018. Penyebab Pengidap Diabetes Rentan Alami Kurap.

Redaksi Halodoc. 23 Desember 2017. Waspada Pengidap Diabetes Terkena Penyakit Tinea Pedis.

Rosida, F, Ervianti, E. 2017. Mikosis superfisialis. Berkala Ilmu Kesehatan Kulit Dan KelaminPeriodical Of Dermatology and Venereology, 29(2).

Saskia,T., Mutiara,H.,2015. Infeksi Jamur Pada Penderita Diabetes Mellitus. Jurnal Majority, 4(7) : 1 6.

Soedarto. 2015. Mikrobiologi Kedokteran. Jakarta : Sagung Seto

Sondakh, C.E.E.J., Thigita, A.P. dan Ferra,O.M. 2016. "Profil Dermatofitosis di poliklinik kulit dan kelamin RSUD prof. Dr. R. D. Kandou Manado Periode Januari-Desember 2013". Jurnal eClinic (ECI), Vol. 4, No. 1, Januari-Juni 2016.

Elma Stasya, E. S., Nurmansyah, D., \& Ramadhani, D. (2018). INFEKSI Candida albicans PADA SWAB MULUT PASIEN DIABETES MELITUS DI RUMAH SAKIT RATU ZALECHA MARTAPURA BULAN JUNI 2018 (AAK Borneo Lestari).

Tandra, H. (2013). Life Healthy with Diabetes Mengapa dan Bagaimana. Yogjakarta: CV Andi Offset.

Vena, G. A. P. Chieco, F. Posa, A. Garofalo, A. Bosco, dan N. Cassano. 2012. Epidemiology Of Dermatophytoses: Retrospective Analysis From 2005 To 2010 And Comparison With Pevious Data From 1975. New Microbiologi, 35, 207-2013.

WHO (Word Health Organization). 2013. Neglected Tropical Diseases. (http://www.who.int/neglected_diseases/diseases/), (Diakses 26januari 2020). 